\title{
Nesting biology of the Australian solitary bee Paracolletes crassipes Smith (Hymenoptera: Colletidae) accords with that of the Diphaglossinae
}

\author{
Terry F. Houston \\ Collections and Research, Western Australian Museum, 49 Kew Street, Welshpool, Western Australia \\ 6106, Australia. \\ Email: terry.houston@museum.wa.gov.au
}

\begin{abstract}
Discovery of an extensive nesting aggregation of Paracolletes crassipes in southwestern Western Australia enabled the first study of the nesting biology of this species and its genus. Nest burrows were excavated in deep loam in a clearing in sclerophyll forest. Like New World Diphaglossinae, females of $P$. crassipes constructed vertically oriented brood cells with strongly curved, polished necks; larval provisions were partly liquid and partly solid; mature larvae spun cocoons with flat tops and produced a clear liquid (evidently from the Malpighian tubules) at the time of defaecation. The cocoons of $P$. crassipes differed from those of other diphaglossines in having solid tops and no covering of the larval faecal masses. Overall, the nesting biology tends to support the inclusion of Paracolletes in the Diphaglossinae.
\end{abstract}

KEYWORDS: brood cells, cocoons, floral preferences, larval provision, mate-seeking

\section{INTRODUCTION}

Paracolletes crassipes Smith is a medium-sized, black, hairy bee that is recorded from both eastern and western Australia (Atlas of Living Australia, accessed March 2020). Western Australian Museum collection records reveal that, in Western Australia, the species occurs south of a line from Jurien to Israelite Bay. Despite its widespread occurrence, its nests and nesting biology have not been documented previously.

In early 2020, the serendipitous discovery of a large nesting aggregation near Waroona in south-western Australia provided an opportunity to glean details of the nesting biology of this species, indeed the genus Paracolletes s. str., for the first time. The present paper summarises the results of studies at the nesting site and in the laboratory and should be of interest to bee systematists and ethologists alike.

Paracolletes crassipes has special significance in being the type-species of the genus Paracolletes Smith, 1853, which is the type-genus of the tribe Paracolletini Cockerell, 1934 (Michener 1986a). Until comparatively recently, this tribe formed part of the subfamily Colletinae and contained all of Australia's hairy, scopabearing colletids and most of those of South America (Michener 1944, 1965, 2007). Unexpectedly, genetic studies (Almeida and Danforth 2009) indicated that $P$. crassipes is more closely related to members of the
New World Diphaglossinae than to other hairy colletids, even including Anthoglossa Smith which Michener $(1965,2007)$ had treated as a subgenus of Paracolletes. Accordingly, Almeida et al. (2012) removed Paracolletes from the clade containing the bulk of the bees previously known as Paracolletini and adopted the subfamily name Neopasiphaeinae (proposed originally as a tribe by Cockerell, 1934) for this assemblage. Paracolletes remained incertae sedis until being included in Diphaglossinae by Almeida et al. (2018).

Because members of the Diphaglossinae exhibit some very distinctive features of nesting biology that sets them apart from other hairy colletids (Rozen 1984; Almeida 2008), details of the nesting biology of Paracolletes s. str. have been keenly awaited.

\section{METHODS AND MATERIALS}

My observations of nests and nesting and mating behaviour were made on Cypress Farm, c. $10 \mathrm{~km}$ ENE of Waroona and c. $94 \mathrm{~km} \mathrm{~S}$. of Perth CBD, Western Australia. I excavated nests and observed adult activity on three occasions in early 2020: 24 January, 29-31 January, and 5-7 March. On 24 January, I began digging where male activity was most intense and females were sighted entering or leaving burrows. Excavation was undertaken using hand tools and the spoil was 
put through a $5 \mathrm{~mm}$ sieve to extract brood cells and live stages. The resultant pit, which reached a depth of $80 \mathrm{~cm}$, was then covered with a sheet of tin until I resumed excavation on 29 and 30 January, extending it on one side. The pit was back-filled on 31 January and a second, smaller excavation was commenced several metres away to trace an open burrow into which a pollen-laden female had been seen entering. During my March visit, I reopened the larger pit, deepening it to $102 \mathrm{~cm}$ and extending it into undisturbed soil on two sides.

Cells containing live stages were refrigerated until they could be returned to the laboratory where they were kept in an insulated box maintained indoors at ambient temperatures. Voucher specimens are lodged in the entomology collection of the Western Australian Museum, Perth.

Bombyliid flies collected at the nesting site were identified with the assistance of David Yeates (Australian National Insect Collection) and keyed using the work of Li and Yeates (2019). Meloid beetles were keyed to genus using the work of Bologna et al. (2013).

Cocoon tops were examined and imaged using a Hitachi TM3030Plus electron microscope.

\section{RESULTS}

\section{NESTING SITE}

On 24 January, I discovered an extensive nesting aggregation of $P$. crassipes in a forest clearing known as 'Donkey Paddock' on Cypress Farm (Figure 1). The clearing was created as the shunting yard for timber loading in the late 1800 s or early 1900 s in a valley floor adjacent to Cypress Brook. The ground was mostly gently sloping with some level areas, the soil a red-brown loam. Initially, I did not see the nests, but a persistent hum drew my attention to males of $P$. crassipes hovering close to the ground at the edge of a vehicle track. There, the ground was covered by dense, very short grass, moss and leaf-litter. Occasionally, males converged on and attempted to copulate with a crawling female and, now and then, a pollen-laden female flew in and disappeared among the grass and litter. Thus, the presence of numerous concealed burrows was revealed. This adult activity extended for approximately $90 \mathrm{~m}$ in a 2-4 $\mathrm{m}$ wide band flanking the track. On later visits, similar adult activity revealed more nest burrows in adjacent areas of the clearing, some being in open bare ground.

Surrounding the clearing was almost pristine sclerophyll forest dominated by Jarrah (Eucalyptus marginata Smith), Marri (Corymbia calophylla (Lindley)) and Swan River Blackbutt (Eucalyptus patens Bentham). During my two January visits, C. calophylla was in heavy flower, but, on my March visit, few flowers remained. No other native plants were observed to be in flower in the area at the same times.

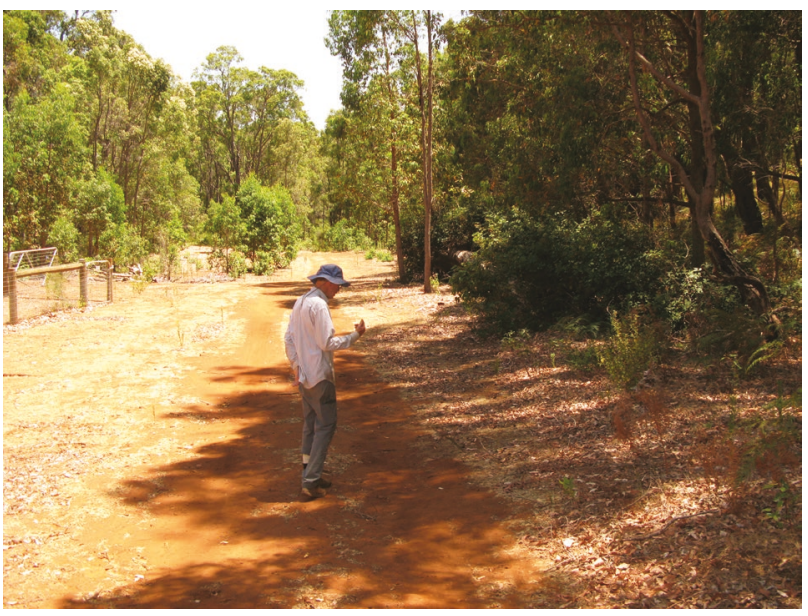

FIGURE 1 Forest clearing where an extensive nesting population of Paracolletes crassipes was studied. Many nest burrows were located just to the right of the track among the leaf litter.

\section{ADULT ACTIVITY AT NESTING SITE}

During my two January visits, males were extremely numerous over the nesting site where they flew in meandering paths one or two centimetres above the grass and litter or the bare ground surface. They frequently landed to investigate holes and, occasionally, they converged upon a female crawling on the ground or litter and attempted to copulate with her. During my March visit, by contrast, no males were observed.

On my first visit to the site (24 January), the day was clear, sunny and very warm. From about 11 am, when my observations commenced, male mate-seeking activity was confined to ground shaded by tall trees. However, as that area became exposed to full sunlight in the early afternoon, it was progressively deserted by the males. On 29 January, under similar conditions, males again patrolled the nesting area until it was exposed to the sun, but, from $2.30 \mathrm{pm}$, males patrolled shaded ground on the opposite side of the clearing. After $4.30 \mathrm{pm}$, males patrolled both sides of the clearing and continued to do so until $7.30 \mathrm{pm}$ when light was fading. On 30 January, cooler, cloudy conditions prevailed following overnight showers and males patrolled the full width of the clearing from 9 am onwards. Even after the cloud broke about $4.30 \mathrm{pm}$, male activity continued over areas receiving full sun.

Females were active on all three of my visits. In January, I observed many fewer females than males and most were sighted returning to burrows, their hind legs laden with whitish pollen. Others were seen hovering over the ground, occasionally landing and scratching at the soil or investigating holes. During my March visit, all females returning to burrows lacked pollen loads and the wing margins of all collected specimens were heavily nicked or tattered. On all days of observation, the numbers of females returning to burrows increased towards evening, the latest arrivals being noted at $7.30 \mathrm{pm}$ when fading light made it difficult to see them. 


\section{NESTS}

Nest entrances, identified by the movement of females in or out, were mostly hidden among grass and leaf litter, but a few were in open bare ground. Some entrances had a small lateral tumulus while others had none. Burrows were difficult to trace because of grass and tree roots or stones, but entered obliquely, c. $20-25^{\circ}$ below horizontal for $10 \mathrm{~cm}$ or more, then gradually became steeper, their walls being unlined. One burrow was followed for 47 $\mathrm{cm}$, at which point its slope was c. $45^{\circ}$.

Many more old, vacated cells and cocoons were excavated than cells containing live stages. They were recovered from depths of $24 \mathrm{~cm}$ to $85 \mathrm{~cm}$. Cells containing live stages were recovered from depths of $30-78 \mathrm{~cm}$. Whether old or new, cells occurred singly, not in clusters. Careful excavation of cells in situ revealed that their long axes were vertical, and they were situated at the ends of rising lateral burrows (Figure 2). Unfortunately, lateral burrows could not be traced to their connections with shafts, so their lengths remain unknown. However, the lateral shown in Figure 2 measured at least $39 \mathrm{~mm}$.

Several cells that appeared to be freshly constructed but lacked provisions had smooth, shining inner walls including the curved 'necks' (Figure 2). When a lump of loam containing half of one such cell was soaked in water, most soil slumped away, but a layer approximately $1 \mathrm{~mm}$ thick surrounding the cavity remained intact, suggesting the soil had been cemented by some secretion. At the broken edges of this cell piece, it was evident that a very delicate membrane of cellophane-like material (CLM) lined the cell cavity and was responsible for the shine, but it was not easily peeled away from the soil.



FIGURE 2 Paracolletes crassipes. Incomplete cell and lateral burrow showing how shining, secreted lining of cell walls continues into curved neck. The cellophane-like cell capsule had not yet been constructed. Scale in $\mathrm{mm}$.
The walls of all cells containing provisions or a cocoon had a second lining of CLM that extended up to (but not into) the curved neck and extended just a few millimetres beyond the cocoon top. This membrane, though very delicate, could be peeled away from the walls and the cocoons.

Lateral burrows of cells containing live stages were soil-filled except for the curved cell necks. The inner end of the barricade was observed in only two cases. It was firm and smooth except for a central concavity, lacked any spiral pattern and was not plug-like. The sizes of cells varied markedly, likely corresponding to the genders of the occupants (females being larger than males in the imago). While newly constructed cells were fragile and broke during excavation, cells containing cocoons had cemented earthen coats and were easily separated from the soil as nodules.

\section{PROVISIONS}

No provisioned cells were recovered during my January visits and only three were found during my March visit. Their walls broke and became soaked with a liquid presumed to be nectar from the provision. In the base of each cell there remained a semisolid mass of whitish pollen. The pollen grains were consistent with being those of Corymbia calophylla.

\section{COCOONS}

Each cocoon filled the entire lumen of the cell below the neck. Despite the close application of the cocoon to the cell walls and the CLM membrane that lined them, the latter could be peeled away easily from cocoons after removal of the surrounding earthen wall.

The top of each cocoon was quite flat and formed a thick, stiff partition across the cell mouth below the curved neck of the cell and several millimetres inside the mouth of the CLM cell capsule (Figure 3). The cocoon top was tilted towards the lateral burrow so that it was not perpendicular to the longitudinal axis of the cell (Figure 4). Consequently, one can distinguish between its upper and lower portions (as distinct from its outer and inner surfaces). Its outer surface was mostly dark brown and slightly shiny, but a narrow strip around its upper rim was pale brown and matt (Figure 5).

The inner surface of the cocoon top (the cocoon ceiling) was mostly flat but, around its circumference, it curved down and merged imperceptibly with the side walls. It was smooth, blackish brown and shiny except for a patch in its upper one quarter to one half which was pale brown and matt (Figure 6).

Sectioning the cocoon top revealed that it was solid and composed for the most part of five layers of silk fibres, each embedded in a polymer matrix (for convenience, I will use the term fibre-reinforced polymer, abbreviated as FRP, for such layers). Between these solid layers were very thin layers of uncemented silk strands, but no air spaces. The cocoon top was 
thinnest (c. $0.3 \mathrm{~mm}$ ) close to its lower edge and became thicker toward its upper edge (Figures 7-8). At the latter, I was able to tease apart about 20 tightly packed layers of silk fibres not embedded in a matrix (Figure 9). These uncemented layers connected the pale areas of the inner and outer surfaces of the cocoon top.

Examination with a scanning electron microscope revealed that most of the upper surface of the cocoon top lacked apertures (Figure 10). However, its pale outer edges consisted of open-weave silk fibres (Figures 1112). The inner surface of the cocoon top was also sealed over most of its area except for a pale patch (Figure 6) which was comprised of open-weave silk fibres (Figure 13).

The side and bottom walls of the cocoon contrasted with the top in being composed of a thin but tough, flexible, translucent brown membrane. This membrane was double-layered 1-3 mm below the cocoon top but
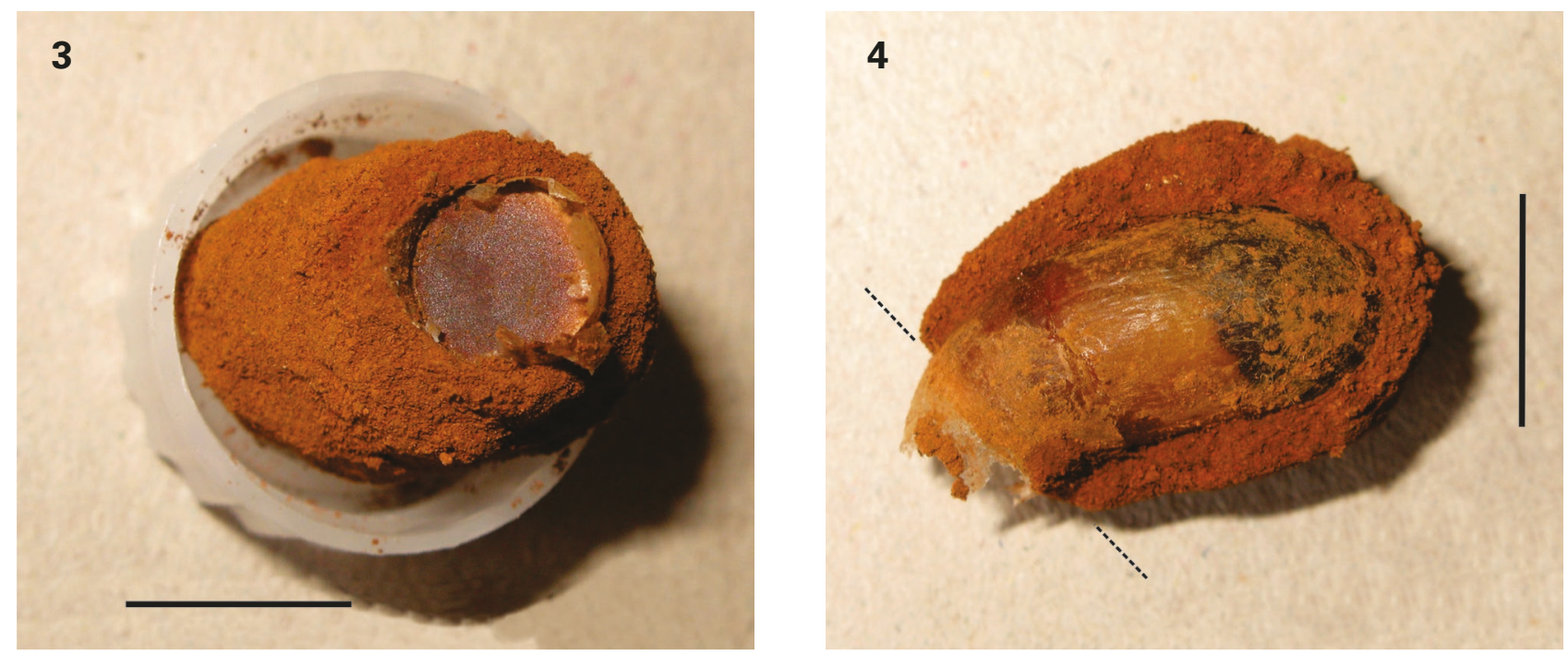

FIGURES 3-4

Paracolletes crassipes. Earth nodule containing a cocoon: 3) top view showing cocoon top surrounded by torn edges of cell capsule; 4) lateral view (broken line indicates plane of cocoon top; whitish prepupa and blackish meconium are visible through translucent side wall of cocoon. Scales $1 \mathrm{~cm}$.
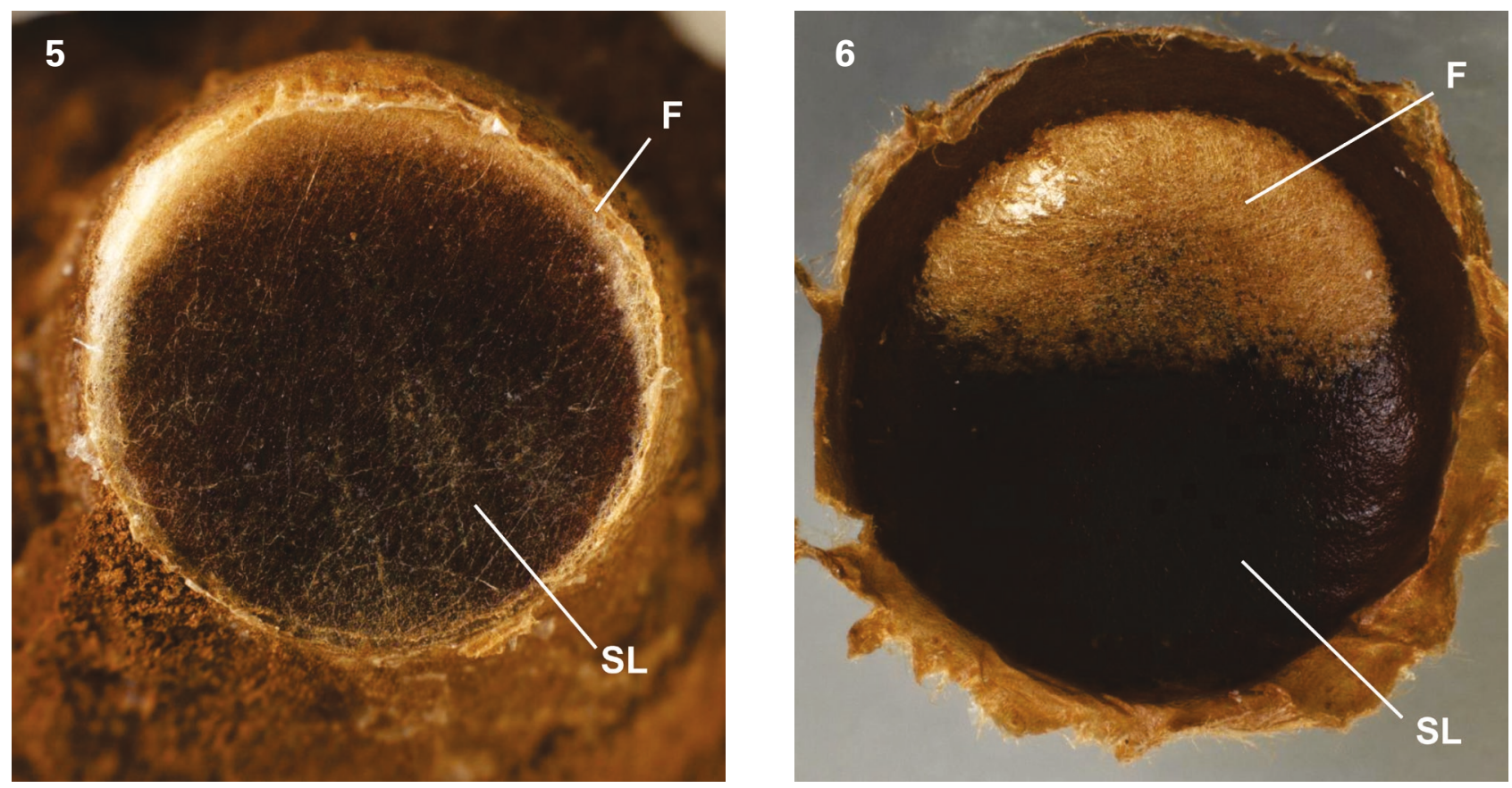
lamina (silk fibres embedded in a secreted matrix). 
changed imperceptibly to single-layered in the lower half. Like the sealed layers of the cocoon top, each layer of the side and bottom walls consisted of FRP and, when torn using jewellers' forceps, silk fibres were exposed along the torn edges.

Several cocoons were opened shortly after being found and most contained an inactive prepupa resting on a blackish meconium. These meconia (Figures 1416) were moulded (more or less) to the rounded lower end of the cocoon but thick in the centre so that the upper surface of each was shallowly concave. In some cases (Figures 15-16), the contours of the undersides of meconia differed from those of the cocoon bases, suggesting air spaces had existed between the two. Individual faeces could be discerned even though they were compressed into a solid mass. No silk was laid on top of the meconium.

Clear liquid droplets were noted inside the side walls of several cocoons with prepupae and a pool of clear, watery liquid was found in one. When this liquid was transferred to a glass vial and warmed on a hotplate, it evaporated leaving a substantial deposit of whitish gummy material. Similar gummy material encrusted parts of the interior of cocoons, including the upper surface of the meconium (Figure 14). This substance, when dissolved in water, was found to contain numerous tiny, white, rounded bodies composed of densely packed spherical granules consistent with being urate crystalloids. A mature larva found in one cocoon was just beginning to defaecate. It was transferred to a glass vial where it continued to produce discrete, semifirm, rod-like faeces and a clear colourless liquid.

Several cells containing intact cocoons were maintained at ambient indoor temperatures. Adults of $P$. crassipes emerged from some of them: in February 2020, a male and a female; in the period 25-30 November 2020, two males and four females.

Most of the old cocoons excavated had perforated tops but several had an intact top and a hole in the side wall.

\section{FORAGE PLANTS}

No sightings of adults at flowers were made at Cypress Farm. In January, the surrounding Marri trees (Corymbia calophylla) were in very heavy flower and this blossom was generally much too high to be reached with an insect net. Nevertheless, it can be assumed that this is where the bees were foraging because there were no other flowers in the area and pollen carried by females and in brood cells was white and composed of myrtaceous grains.

Collection records in the WA Museum indicate that P. crassipes forages only at Myrtaceae: Corymbia calophylla, Eucalyptus and Melaleuca. Additionally, I have seen photographs of females on flowers of $M$. huegelii Endl. and M. lanceolata Otto courtesy of Kerry Stuart and John Szymanski. All known forage plants are white-flowered.


FIGURES 7-9 Paracolletes crassipes. Cocoon: 7) top sectioned across middle, viewed laterally, slightly from above; 8) same viewed slightly from below; 9) enlargement of part of Figure 7 showing layers of unconsolidated silk fibres somewhat teased apart. 

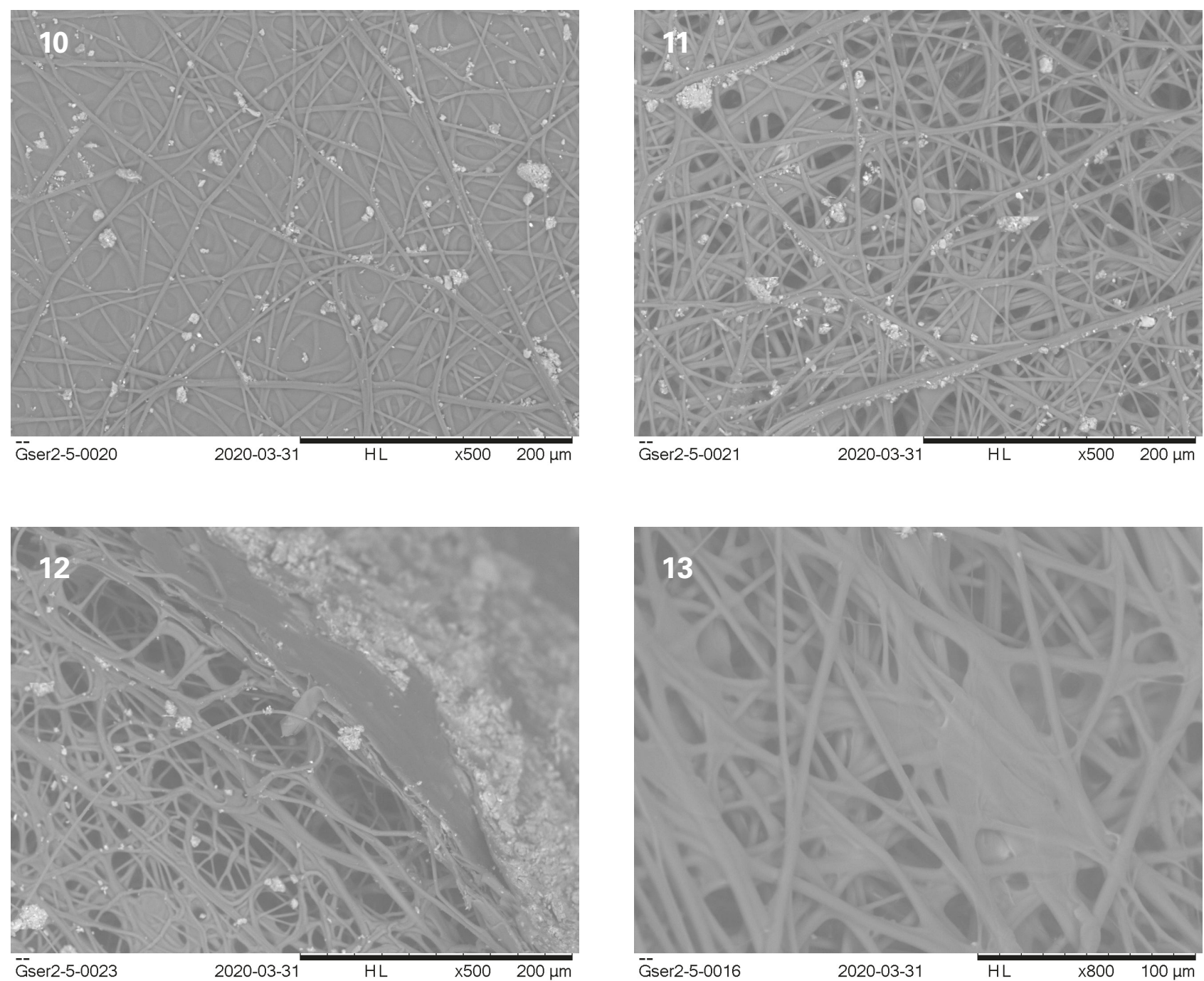

FIGURES 10-13 Paracolletes crassipes. Cocoon top imaged using a scanning electron microscope: 10) outer surface, central, solidly sealed section; 11) outer surface, open-weave fibres of pale marginal area; 12) outer surface, same immediately adjoining cocoon side wall; 13) open-weave silk fibres forming part of pale area of inner surface.

\section{ASSOCIATED ORGANISMS}

Females of the bombyliid fly Sisyromyia aurata (Walker, 1849) were observed during my January visits hovering over the nesting area and many appeared to be dropping eggs into the grass and litter. Numerous larvae and pupae likely to be those of this fly were found in burrows during excavation. A tiny fly belonging to an unidentified genus of Phoridae was found in one freshly provisioned cell and 37 tiny maggots consistent with being those of phorids were found in another cell containing pollen. Unfortunately, none of the above dipteran larvae developed into adults.

Two adults of a meloid beetle (Australozonitis sp.) were found at the excavation site, one dead on the ground and one live in the pit. As well, two coarctate larvae found in brood cells lacking cocoons were typical of Meloidae. Lumps of black material adhering to the cell walls close to the mouth of one such cell were composed of pollen grains consistent with being those of Eucalyptus.

\section{DISCUSSION}

Judging by the large number of old, soil-filled cells and cocoons recovered during excavation, the nesting site was a perennial one. The absence of tumuli of any significant size at nest entrances might suggest reuse of old burrows. Most nest entrances observed were hidden among short grass and moss and under leaflitter, although a few were observed in bare ground. It is a moot point whether females select such places to commence new burrows or whether vegetation grows over a previously bare nesting area in which burrow reuse is occurring. Certainly, hidden nest entrances are known for some neopasiphaeine bees (formerly Paracolletini) (Houston 2020).

An unusual feature of male behaviour was that, on hot days, mate-seeking flights were confined to shaded areas of the nesting ground, whereas on cool days, males searched both shaded and sun-lit areas. Evidently, temperature was the controlling factor rather than light 
intensity. Many New World diphaglossine bees are adapted for dim-light or nocturnal foraging (Wcislo and Tierney 2009) but $P$. crassipes is clearly diurnal, flying throughout the day. It was notable, though, that many females were observed returning to nests in evening twilight.
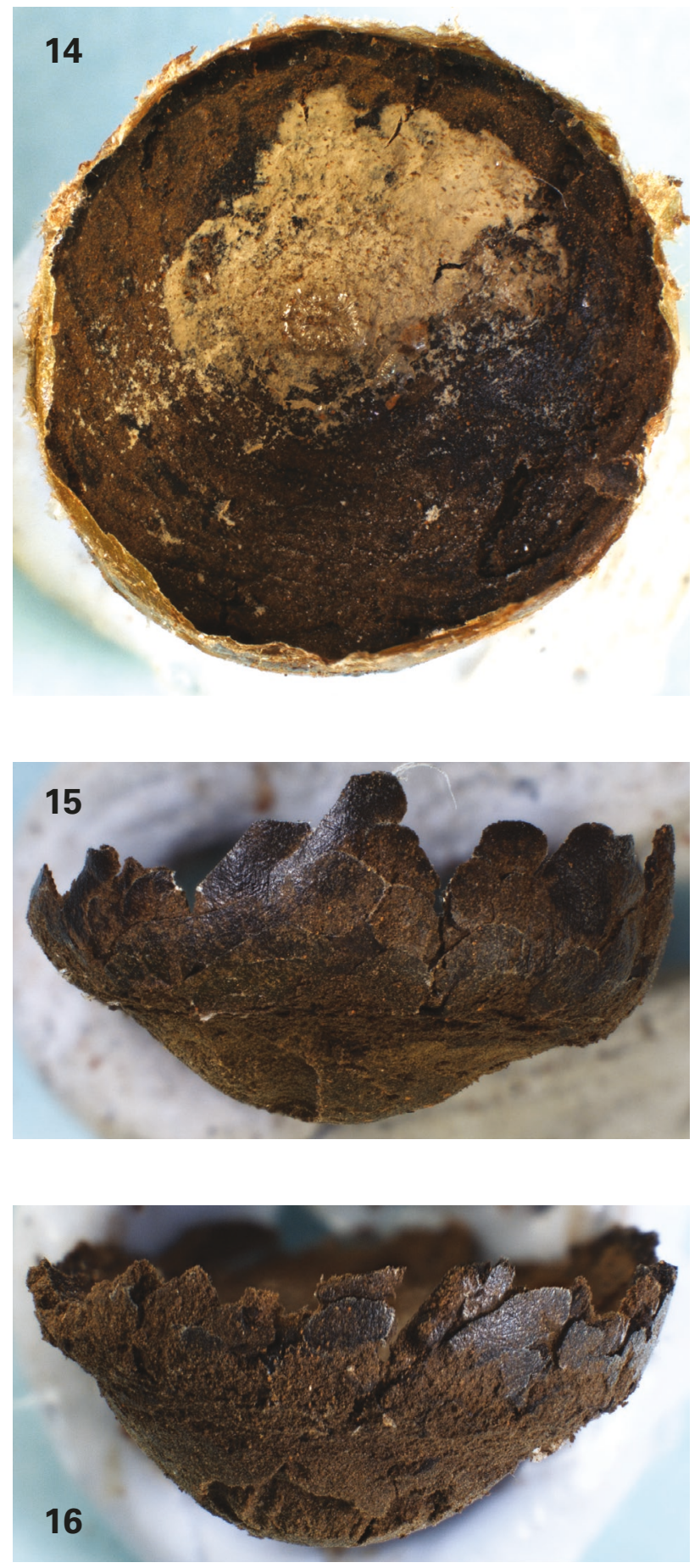

FIGURES 14-16 Paracolletes crassipes. Meconia: 14) top view of meconium in base of cocoon showing upper layer of whitish, gummy material; 15-16) two meconia removed from cocoons, lateral view (note contours of undersides do not conform completely to rounded bases of cocoons).
At the time of my January visits, the frequency of matings and the number of females searching for nesting sites suggested that a new generation of adults was commencing its nesting cycle, coinciding with a mass flowering of Corymbia calophylla. Collection records for $P$. crassipes held by the WAM reveal that in southwestern Australia adults are active from December to March. Associated floral visitation records suggest that the bee limits its foraging to a few species of the genera Eucalyptus, Corymbia and Melaleuca (all Myrtaceae). Clearly the species must have more than one generation per year. At Cypress Farm (and in the south-western sclerophyll forests generally) there is a succession of flowering in the order E. marginata, E. patens and C. calophylla (Coleman 1962), covering the bee's flight period.

Only eight of many cocoons collected in January yielded adults and ten cocoons remained intact on 14 December 2020. This is in keeping with knowledge that some prepupae of many solitary bees remain dormant for two or more generations as insurance against poor seasons (Michener 2007).

I was not able to determine the architecture of individual nests because of obstacles such as roots and rock in the soil. However, because freshly made brood cells and occupied cocoons occurred singly, not in clusters, and were distributed through at least $50 \mathrm{~cm}$ of the soil profile to a depth of $85 \mathrm{~cm}$, I infer that females construct their cells singly at wellseparated intervals along their shafts. This is the pattern recorded for certain diphaglossines in the genera Diphaglossa Spinola, Ptiloglossa Smith and Zikanapis Moure (= Caupolicana Spinola) (Roberts 1971; Rozen 1984; Sarzetti et al. 2013). Nest architecture of neopasiphaeines is poorly documented but lateral burrows of some species radiate from the lower end of the shaft (Michener 1960; Houston and Maynard 2012) while those of Lonchopria cingulata are concentrated about the shaft's lower extremities (Michener and Lange 1957).

The formation of soil nodules around older brood cells is not unique to $P$. crassipes, having been observed also in the diphaglossine Caupolicana yarrowi (Cresson) (Rozen et al. 2019), the neopasiphaeine Trichocolletes orientalis Batley and Houston (Houston 2020) and some Stenotritidae (Houston 1984; Houston and Thorp 1984; Houston 1987). In the case of C. yarrowi, Cane and Rozen (2019) found evidence that females impregnate their cell walls with nectar, enabling them to trowel them to a smooth finish prior to applying a waterproof lining. Perhaps this behaviour is widespread among burrowing bees.

Diphaglossinae exhibit some characteristics of nesting biology that distinguish them from other hairy colletids (Rozen 1984; Sarzetti et al. 2013; Sarzetti et al. 2014): cells are vertically oriented, have strongly curved necks that are varnished like the remainder of the cell walls and are closed by a cell plug that is thin and 
situated in the curved neck (a conspicuous exception is Cadeguala occidentalis (Haliday) which builds a thick plug in the cell mouth (Torchio and Burwell (1987)); the larval provision is partly liquid; mature larvae spin cocoons; and the cocoons have a flat top. Paracolletes crassipes shares most of these characteristics but appears not to construct a cell plug (unless the smooth inner end of the barricade filling the lateral burrow equates to a plug).

Some Australian Neopasiphaeinae, notably Anthoglossa Smith and Trichocolletes Cockerell, also construct vertical brood cells and have a liquid provision, but none is known to construct curved, varnished cell necks or larval cocoons (Houston 2018, 2020). Comparison of nesting biology across taxa of hairy colletids is hampered because information is lacking for some key groups: (a) Anthoglossa, treated as a subgenus of Paracolletes by Michener (1965, 2007); (b) the diphaglossine tribe Dissoglottini (particularly the genus Mydrosomella Michener which contains small species 'with the superficial appearance of some Paracolletini' (Michener 1986b).

Diphaglossinae are the only Colletidae known to construct cocoons according to various authors (Michener 2007; Almeida 2008; Danforth et al. 2019). However, Michener and Lange (1957) recorded finding prepupae of the Brazilian bee Colletes michenerianus Moure, each enclosed in 'a very thin, light brown cocoon made up of fibers, with the spaces between the fibers filled with pale brown amorphous material. The cocoon was constructed against and adhered to the cellophanelike material of the nest except where feces were between the cocoon and the nest material'. The significance of their find was apparent to the authors who remarked that 'This is the only Colletes that we know that constructs a cocoon.' To my knowledge, this record has not been refuted.

Cocoon spinning is regarded as a plesiomorphic character state within the Hymenoptera and has been lost independently in various groups of bees (Rozen 1984; Radchenko and Pesenko 1996; Michener 2007; Almeida 2008; Danforth et al. 2019). Furthermore, cocoons may be spun by one generation of a species and not another, or the form of the cocoon may vary between generations (Mello and Garófalo 1986; Rozen 1993). Clearly, cocoon spinning is a habit that is easily 'switched off' or modified. Consequently, we should be wary of attaching too much significance to its presence or absence in establishing relationships among taxa. However, certain features of a cocoon might be considered derived and therefore of more use in phylogenetics. The cocoons of Diphaglossinae (including Paracolletes) differ from those of other bees in their flat tops. Rozen (1984) recognized three distinct layers in the cocoon tops of several New World diphaglossines: the flat outermost layer ('operculum') which was parchment-like but fenestrated, the concave innermost layer ('ceiling'), also parchment-like and fenestrated and, between these two, a zone of varying thickness filled with loosely woven silk ('filter'). Such an arrangement was presumed by some authors (e.g. Roberts 1971; Rozen 1984) to permit gaseous exchange between the cocoon lumen and the soil. The cocoon top of $P$. crassipes is a thinner, more solid structure, with the operculum and ceiling lacking fenestrations and being separated from one another by laminae but no air spaces. Presumably, the acentric patch of densely woven, multilayered and unsealed silk fibres in the cocoon top of $P$. crassipes equates to the filter of New World diphaglossines and serves the same purpose.

Among various cocoon-spinning bees, differences occur in the timing of defaecation with respect to cocoon spinning so that faeces may remain external to the cocoon, become incorporated in its outer walls or be enclosed within the cocoon (Stephen et al. 1969; Rozen 1984, 1993; Danforth et al. 2019). In most New World diphaglossines studied to date, faeces are deposited in the bottom of the cell as a solid mass (meconium) when the cocoon is only partially constructed. In some cases, the walls of the cocoon do not extend to the base of the cell, while in other cases they do, but in a more porous form. Then, once the meconium has been formed, the larva lays a parchment like layer over its top to form the floor of the cocoon (Rozen 1984). In Cadeguala occidentalis, a thin, cup-shaped meconium is sealed between inner and outer cocoon layers (Torchio and Burwell 1987). Larvae of P. crassipes behave differently, defaecating only upon completion of the cocoon and not covering the meconium with any spun material. Mature larvae of apoid and vespoid wasps behave similarly (Evans and Eberhard 1973; Gess 1996) and this behaviour must therefore be viewed as plesiomorphic.

A clear liquid or a white, gummy material left when the liquid dries was found in many cocoons of $P$. crassipes. These substances were likely to be products of the Malpighian tubules of final instar larvae, given the presence of urate bodies in the dried material. Mature larvae of the diphaglossine Crawfordapis luctuosa Smith also deposit clear liquid on top of their faecal masses (Roubik and Michener 1985) and Rozen (1984) surmised that the larvae were eliminating water ingested with the liquid provisions. It is pertinent to note, therefore, that the larval provision of $P$. crassipes also has a significant liquid component. Larvae of Neopasiphaeinae are not known to produce liquid waste, but those of Colletes ciliatoides Stephen (Colletinae sensu Almeida et al. 2018) produce a clear gel-like material from the anus and spread it over the faecal mass where it dries like a varnish (Torchio 1965).

The need to rid cells of excess water contained in faeces is believed by Rozen (1984) to have led to an interesting behaviour in mature larvae of some New World diphaglossines (Cadeguala and Ptiloglossa species): they perforate or destroy the CLM lining of the bottoms of their cells with their mandibles before 
completing their cocoons, allowing water from wet faeces to soak into the soil. No such perforation was observed for $C$. luctuosa or $P$. crassipes and their cocoon bottoms are impermeable.

In summary, the observations recorded in this study are largely consistent with the current (Almeida et al. 2018) placement of Paracolletes crassipes in the Diphaglossinae. So, it is confounding that adults of $P$. crassipes do not key to this subfamily. The diagnostic features of Diphaglossinae have changed over time along with the concept of the taxon (e.g. Michener 1966, 1986b, 2007) and in Michener's (2007) key to subfamilies of Colletidae, the Diphaglossinae are distinguished from other hairy colletids by just two characteristics: (1) stigma much reduced; (2) glossa deeply bifid with the apical lobes directed apicolaterally. Paracolletes has a very small stigma (as do some other hairy colletids including the Australian taxa Anthoglossa, Hesperocolletes Michener and Trichocolletes) but its glossa is not at all bifid. Relative size of the stigma alone is not a reliable taxonomic character for, as Danforth (1989) demonstrated, it is inversely proportional to body size across a range of bee taxa.

\section{ASSOCIATED ORGANISMS}

Circumstantial evidence gathered during this study points to a parasitic association between the moderately large bee fly, Sisyromyia aurata, and P. crassipes. Larvae and pupae presumed to be of this fly seemed to be very mobile and several dropped out of the walls of my excavation, but none was observed in a brood cell of the bee. Perhaps it is their depredations that account for the considerable number of empty cells observed.

A more definite parasitoid was a meloid species, coarctate larvae of which were found resting in brood cells.

It was surprising that no hymenopteran parasitoids such as gasteruptiids, mutillids or ichneumonids (especially Labium) were found to be associated with nests of $P$. crassipes. They are frequently found in association with other Australian ground-nesting bees.

The exceptionally tough cocoon top of $P$. crassipes might explain why some occupants (presumably parasitoids) had exited through the cocoon side walls.

\section{ACKNOWLEDGEMENTS}

I am most grateful to Kingsley Dixon and Lionel Johnston, owners of Cypress Farm, for facilitating my studies of $P$. crassipes on their property, for their hospitality and for assisting with excavation of nests. My sincere thanks also to David Yeates (ANIC) for assisting me to identify the bombyliid fly and Geoff Deacon (WAM) for providing the scanning electron micrographs of cocoons constituting Figures 10-13. The collection of specimens was covered by a permit from the WA Department of Biodiversity, Conservation and Attractions. Eduardo Almeida (University of São Paulo) and Laurence Packer (York University, Toronto) read an early draft of my manuscript and provided helpful suggestions for its improvement.

\section{REFERENCES}

Almeida, E.A.B. (2008). Colletidae nesting biology (Hymenoptera: Apoidea). Apidologie 39: 16-29. doi: 10.1051/apido:2007049.

Almeida, E.A.B. and Danforth, B.N. (2009). Phylogeny of colletid bees (Hymenoptera: Colletidae) inferred from four nuclear genes. Molecular Phylogenetics and Evolution 50: 290-309. doi: 10.1016/j.ympev.2008.09.028.

Almeida, E.A.B., Pie, M.R., Brady, S.G. and Danforth, B.N. (2012). Biogeography and diversification of colletid bees (Hymenoptera: Colletidae): emerging patterns from the southern end of the world. Journal of Biogeography 39: 526-544. doi: 10.1111/j.1365-2699.2011.02624.x.

Almeida, E.A.B., Packer, L., Melo, G.A.R., Danforth, B.N., Cardinal, S.C., Quinteiro, F.B. and Pie, M.R. (2018). The diversification of neopasiphaeine bees during the Cenozoic (Hymenoptera: Colletidae). Zoologica Scripta 48: 226-242. doi: $10.1111 /$ zsc. 12333 .

Atlas of Living Australia. Accessed from https://www.ala.org. $\mathrm{au} /$

Bologna, M.A., Turco, F. and Pinto, J.D. (2013). The Meloidae (Coleoptera) of Australasia: a generic review, descriptions of new taxa, and a challenge to the current definition of subfamilies posed by exceptional variation in male genitalia. Invertebrate Systematics 27: 391-427. doi: 10.1071/IS12054.

Cane, J.H. and Rozen, J.G., Jr. (2019). Appendix: The desert bee Caupolicana yarrowi (Colletidae) uses nectar for nest construction. American Museum Novitates 3931: 18-20.

Coleman, R.S. (1962). Bee farming: honey flora of Western Australia. Journal of the Department of Agriculture, Western Australia, (Ser. 4) 3 (8): Article 21. Available from: https://researchlibrary.agric.wa.gov.au/journal_agriculture4/ vol3/iss $8 / 21$

Danforth, B.N. (1989). The evolution of hymenopteran wings: the importance of size. Journal of Zoology, London 218: 247-276.

Danforth, B.N., Minckley, R.L. and Neff, J.L. (2019). The Solitary Bees: Biology, Evolution, Conservation. Princeton University Press, New Jersey/Oxfordshire; xi + 472 pp.

Evans, H.E. and West Eberhard, M.J. (1973). The Wasps. David and Charles (Holdings) Ltd, Newton Abbot; vi +265 pp.

Gess, S.K. (1996). The Pollen Wasps: ecology and natural history of the Masarinae. Harvard University Press, Cambridge; $X+340$ pp.

Houston, T.F. (1984). Biological observations of bees in the genus Ctenocolletes (Hymenoptera: Stenotritidae). Records of the Western Australian Museum 11: 153-172.

Houston, T.F. (1987). A second contribution to the biology of Ctenocolletes bees (Hymenoptera: Apoidea: Stenotritidae). Records of the Western Australian Museum 13: 189-201.

Houston, T.F. and Thorp, R.W. (1984). Bionomics of the bee Stenotritus greavesi and ethological characteristics of Stenotritidae (Hymenoptera). Records of the Western Australian Museum 11: 375-385.

Houston, TF. 2018. A Guide to Native Bees of Australia. CSIRO Publications, Clayton South; vii +272 pp. 
Houston, T.F. (2020). On the remarkable nesting biology of an Australian bee in the genus Trichocolletes Cockerell (Hymenoptera: Colletidae). Austral Entomology 59: 593601. doi: 10.1111/aen.12462.

Houston, T.F. and Maynard, G.V. (2012). An unusual new paracolletine bee, Leioproctus (Ottocolletes) muelleri subgen. and sp. nov. (Hymenoptera: Colletidae): with notes on nesting biology and in-burrow nest guarding by macrocephalic males. Australian Journal of Entomology 51: 248-257. doi: 10.1111/j.1440-6055.2012.00867.x.

Houston, T.F. and Thorp, R.W. (1984). Bionomics of the bee Stenotritus greavesi and ethological characteristics of Stenotritidae (Hymenoptera). Records of the Western Australian Museum 11: 375-385.

Li, X. and Yeates, D.K. (2019). Revision of the Australian bee fly genus Sisyromyia White, 1916 (Bombyliidae, Bombyliinae, Acrophthalmydini). Zootaxa 4711: 201-244. doi: 10.11646/zootaxa.4711.2.1.

Mello, M.L.S. and Garófalo, C.A. (1986). Structural dimorphism in the cocoons of a solitary bee, Lithurge corumbae (Hymenoptera, Megachilidae) and its adaptive significance. Zoologische Anzeiger 217: 195-206.

Michener, C.D. (1944). Comparative external morphology, phylogeny, and a classification of the bees (Hymenoptera). Bulletin of the American Museum of Natural History 82: 151-326.

Michener, C.D. (1960). Notes on the behavior of Australian colletid bees. Journal of the Kansas Entomological Society 33: $22-31$.

Michener, C.D. (1965). A classification of the bees of the Australian and South Pacific regions. Bulletin of the American Museum of Natural History 130: 1-362, pls 1-15.

Michener, C.D. (1966). The classification of the Diphaglossinae and North American species of the genus Caupolicana (Hymenoptera, Colletidae). The University of Kansas Science Bulletin 46: 717-751.

Michener, C.D. (1986a). Family-group names among bees. Journal of the Kansas Entomological Society 59: 219-234.

Michener, C.D. (1986b). A review of the tribes Diphaglossini and Dissoglottini (Hymenoptera, Colletidae). The University of Kansas Science Bulletin 53: 183-214.

Michener, C.D. (2007). The Bees of the World, $2^{\text {nd }}$ edition, The Johns Hopkins University Press, Baltimore; xvi + 953 pp.

Michener, C.D. and Lange, R.B. (1957). Observations on the ethology of some Brazilian colletid bees (Hymenoptera, Apoidea). Journal of the Kansas Entomological Society 30: 71-80.

Radchenko, V.G. and Pesenko, Y.A. (1996). "Protobee" and its nests: A new hypothesis concerning the early evolution of Apoidea (Hymenoptera). Entomological Review 75 : 140-162.

Roberts, R.B. (1971). Biology of the crepuscular bee Ptiloglossa guinnae n. sp. with notes on associated bees, mites and yeasts. Journal of the Kansas Entomological Society 44: 283-294.

Roubik, D.W. and Michener, C.D. (1985). Nesting biology of Crawfordapis in Panama. Journal of the Entomological Society of Kansas 57: 662-671.

Rozen, J.G., Jr. (1984). Nesting biology of diphaglossine bees (Hymenoptera, Colletidae). American Museum Novitates 2786: $1-33$.

Rozen, J.G., Jr. (1993). Nesting biologies and immature stages of the rophitine bees (Halictidae) with notes on the cleptoparasite Biastes (Anthophoridae) (Hymenoptera: Apoidea). American Museum Novitates 3066: 1-28.

Rozen, J.G., Jr, Danforth, B.N., Smith, C.S., Decker, B.L., Dorian, N.N., Dority, D., Kilpatrick, S.K., Krichilsky, E., Laws, A.N., Urban-Mead, K.R. (2019). Early nesting biology of the bee Caupolicana yarrowi (Cresson) (Colletidae: Diphaglossinae) and its cleptoparasite Triepeolus grandis (Friese) (Apidae: Nomadinae). American Museum Novitates 3931: 1-20. doi: 10.1206/3931.1.

Sarzetti, L.C., Dinghi, P.A., Genise, J.F., Bedatou, E. and Verde, M. (2014). Curved fossil bee cells as tools for reconstructing the evolutionary history and palaeogeographical distribution of Diphaglossinae (Apoidea, Colletidae). Palaeontology 57: 447-455. doi: 10.1111/pala.12074.

Sarzetti, L.C., Genise, J.F., Sánchez, M.V., Farina, J.L. and Molina, M.A. (2013). Nesting behavior and ecological preferences of five Diphaglossinae species (Hymenoptera, Apoidea, Colletidae) from Argentina and Chile. Journal of Hymenoptera Research 33: 63-82. doi: 10.3897/jhr.33.5061.

Stephen, W.P., Bohart, G.E. and Torchio, P.F. (1969). The Biology and External Morphology of Bees. Agricultural Experiment Station, Oregon State University, Corvallis; ii +140 pp.

Torchio, P.F. (1965). Observations on the biology of Colletes ciliatoides (Hymenoptera: Apoidea, Colletidae). Journal of the Kansas Entomological Society 38: 182-187.

Torchio, P.F. and Burwell, B. (1987). Notes on the biology of Cadeguala occidentalis (Hymenoptera: Colletidae), and a review of colletid pupae. Annals of the Entomological Society of America 80: 781-789.

Wcislo, W.T. and Tierney, S.M. (2009). Behavioural environments and niche construction: the evolution of dim-light foraging in bees. Biological Reviews 84: 19-37. doi: 10.1111/j.1469-185X.2008.00059.x.

MANUSCRIPT RECEIVED 1 OCTOBER 2020; ACCEPTED 14 DECEMBER 2020. 